\title{
CZESLAW GRAJEWSKI
}

Cardinal Stefan Wyszyński University in Warsaw

\section{ROMEO AND JULIET BY PYOTR TCHAIKOVSKY. THE 400TH ANNIVERSARY OF WILLIAM SHAKESPEARE'S DEATH}

Describing an event or spinning a fictitious tale does not seem a tall order even for a person of average talent. However, doing the above by advanced literary means or rendering it in painting is no doubt possible only for people who are especially gifted, such as writers, poets and playwrights. Arguably the hardest task is to include an event or a story within a musical work without a text. How to compose an instrumental work that is a musical narrative?

The idea of sound painting is not new. Antiquity knew onomatopoeic means allowing for a certain degree of illustration of music. Composers of the Renaissance, an era in the history of music where the process of separating instrumental and vocal music began, boldly created works meant to be carriers of extra-musical messages. The caccia was perhaps the musical genre best suited to this effect. Apart from the hunting scenes characteristic of it, Renaissance and later Baroque and Classical composers drew on other ideas naturally suitable for musical reproduction, such as battle scenes, animal voices or weather phenomena. However, it was only the subsequent development of compositional technique, an increase in the importance of the subjective element in musical creation and the expansion of the possibilities of musical instruments that led during Romanticism to the creation of programmatic music, whose authors depict in it their personal experiences or essentially all non-musical content. This musical programme is usually contained in the title or subtitle of the composition. Let us list for example: Hector Berlioz's Fantastical Symphony: Episode in the Life of an Artist, Franz Liszt's The Faust Symphony and The Dante Symphony, Modest Mussorgsky's Pictures at an Exhibition, Jean Sibelius's Finland, Zygmunt Noskowski's Steppe, and many others.

Felix Mendelssohn's oeuvre contains an interesting if ephemeral phenomenon of song without lyrics (Lieder ohne worte). It is a series of 48 compositions, lyrical piano miniatures that closely imitate songs thanks to their evocative and flexible melody line with accompaniment. Highly popular among them is Spring Song Op. 62 No. 6, arranged multiple times for different sets of instruments.

What could be the most appropriate subject matter for the art of the Romantic era, if not love, with death in the background? The overture-fantasia Romeo and Juliet based on William Shakespeare's early play and composed by Pyotr Ilyich Tchaikovsky is precisely such a drama, without words and without action.

It is worth noting at the beginning that the story of the unhappy love of lovers from Verona told by the great playwright became the basis of a long series of musical works 
composed up to the present day. A few compositions stand out from this long list. The subject matter was first taken up by Georg Benda in the singspiel Romeo and Juliet (1776), followed by Vincenzo Bellini in the opera I Capuleti e i Montecchi (1830), Hector Berlioz in the dramatic symphony Romeo and Juliet $(1839)^{1}$, and Charles Gounod in his Romeo and Juliet opera (1867). Following Tchaikovsky (1869), Shakespeare's play was taken advantage of by e.g. Sergey Prokofiev in his ballet Romeo and Juliet (1936) and the Polish composer Bernadetta Matuszczak in the chamber opera Juliet and Romeo (1967). Evidently, Pyotr Ilyich Tchaikovsky (1840-1893) is but one of the multiple authors who immortalised the literary motif of Romeo and Juliet in music.

It is worth familiarising ourselves with the biography of this leading representative of Russian Romanticism, as it may provide an answer to the question of inspiration for this beautiful work ${ }^{2}$. The artist was born on April 25 / May 7, 1840 in Votkinsk, in the Russian Empire. His parents were engineer Ilya Petrovich Tchaikovsky and a daughter of French emigrants, Ilya's second wife Alexandra Andreyevna neé d'Assier. The Tchaikovskys did not have musical traditions even if Pyotr's father was interested in musical performance and Alexandra had a good voice and played the harp.

From the age of five, he was taught French, German, and possibly also the basics of piano playing by the young governess Fanny Durbach (1822-1895). Her notes offer an insight into young Pyotr's life. For example, she believed that music had a disastrous effect on him, as it intensified his strong emotions ${ }^{3}$. The composer was very strongly attached to his mother. There is a description of an event when Alexandra was to leave home for a longer time and ten-year-old Pyotr desperately clung to the carriage, unwilling to part with his mother ${ }^{4}$. Shortly afterwards, when he was 14 , his mother died. This tragedy and left a clear mark on his later life and he was unable to establish adequate emotional relations with women.

In fact, he did not have a home all his life: already at the age of 8 he was placed in a boarding school in Petersburg. Between 1850 and 1859, he studied, initially in the entrance class of the Law School, after which he started working for the Ministry of Justice. During his legal training, the future composer continued learning to play the piano (1855-1858) with pianist Rudolf Kündinger (1832-1913), to whom he probably presented his first piano composition Anastasie Valse (1854). As a fluent speaker of the French language, he first went abroad (1861 - Germany, France, the Netherlands, England) as a translator/interpreter and secretary to engineer Vasily Pisariev. Pyotr will make many more trips abroad in his life.

Tchaikovsky did not immediately resign from his previous work when he began his musical studies, but in the end music prevailed over the law when he first became a student of the Russian Music Society in 1861 and the following year of the newly-opened Petersburg Conservatory of Music. In 1865, receiving the so-called silver medal, Tchaikovsky completed his studies in composition and instrumentation under the direction of the founder of the

\footnotetext{
1 Incidentally, H. Berlioz displayed an interest in Shakespeare's King Lear, which served as a basis for his 1831 symphony overture under this very title. In 1873 P. Tchaikovsky himself composed a fantasia for an orchestra titled The Tempest, and in 1888 the overture Hamlet, both after Shakespeare. E. Dziębowska, "Czajkowski", in: Encyklopedia Muzyczna PWM, vol. cd, ed. E. Dziębowska, Kraków 1984, p. 293.

2 Unless otherwise specified, data provided after: E. Dziębowska, op. cit., pp. 281-314.

3 It is unclear if F. Durbach actually taught Pyotr; he may have had lessons from his home tutor Maria Palchikova.

S. Mundy, Czajkowski, transl. E. Pankiewicz, Kraków-Warszawa 2005, p. 16.

4 Ibidem, p. 23.
} 
Conservatory, Anton Rubinstein (1829-1894). On receipt of his diploma he left for Moscow, where he started work in the Moscow Conservatory founded by Nikolai Rubinstein (1835-1881), Anton's younger brother, who admired and promoted Pyotr Tchaikovsky's music. Pyotr would later turn out a good pianist and a still better composer, yet symphony conducting was for a long time a true nightmare for him ${ }^{5}$.

In the late 1868, Tchaikovsky fell in love with the Belgian operatic singer of European renown Marguerite Désirée Artôt (1835-1907), who at that time stayed in Moscow with an opera troupe. However, the mutual interest and plans of marriage did not materialise. Pyotr most probably expected Marguerite to abandon her life as an artist and settle down in Russia, while she recognised she would need a man who would share her unscheduled life. The troupe left Moscow and in Warsaw the singer got engaged to a colleague, the Spanish singer Mariano Padilla y Ramos 6 .

At that time the composer had already seen world premieres of some of his works. At the end of 1869 he composed the first version of the fantasy-overture Romeo and Juliet (to be followed by two other versions). At the end of 1874 he introduced A. Rubinstein to the first part of this First Piano Concerto in B flat minor Op. 23. The master, as it sometimes happens, did not think too highly of the score and strongly criticized the composition. $\mathrm{He}$ announced that he would not perform it until far-reaching corrections had been made in accordance with his recommendations. Such a position became a catalyst for a sharp conflict between the two artists. Despite the argument and Tchaikovsky's reluctance to introduce corrections, though, Anton Rubinstein directed the performance of the concerto in Moscow (1875) in the composer's presence. The soloist at that time was Sergei Taneyev, a student of both Rubinstein's and Tchaikovsky's, later director of the Moscow Conservatory. That year marks the beginning of friendship between P. Tchaikovsky and S. Taneyev. History proved Pyotr Tchaikovsky right, as the Concerto in B flat minor is one of the most magnificent, best recognisable and most often performed piano concertos.

Interestingly, at that time P. Tchaikovsky starts to consistently aspire to fame, even though the beginnings were tough. Apart from world premieres of his works, at times enthusiastically received (Kiev 1874), also abroad (Boston 1875) 7 , he accepts commissions for works to be performed on stage (e.g. Swan Lake 1875, completed in 1876), and receives awards of composers' competitions (1875, 1884 for the fantasy-overture Romeo and Juliet). Both in Moscow and during successive trips abroad he becomes acquaintance of renowned composers and musicians, such as Hector Berlioz, Camille Saint-Saëns, Leopold Auer, and others, including Russian artists.

It would seem that the arduously earned career should be followed by the artist's personal success, yet some less obvious aspects appear in Pyotr Tchaikovsky's biography. At the end of 1876 one of the most intriguing events in the history of music begins, as the composer, solely by means of letters, begins a bizarre acquaintance with Nadezhda von Meck (1831-1894). At the age of 17 she married the entrepreneur Karl von Meck, after whose death in 1876 she inherited a fortune. She herself, brought up to appreciate art, especially music, and fascinated

\footnotetext{
See ibidem, p. 60 .

See ibidem, p. 83.

7 World premieres of some works (e.g. Romeo and Juliet, Piano Concerto in B flat minor, Swan Lake, the Fourth Symphony, The Sleeping Beauty) were not favourably received by the public and the critics.
} 
by R. Wagner's oeuvre, followed in the footsteps of King Ludwig II of Bavaria and became a patron of composers and musicians, especially Pyotr Tchaikovsky. Their correspondence is exceptionally extensive ${ }^{8}$, yet interestingly they most probably never met in person, even in early 1884, during the wedding reception in Petersburg of P. Tchaikovsky's niece Anna Davydova and Nadezhda's son Nikolai von Meck ${ }^{9}$. Still, Nadezhda continued to regularly support the composer financially and therefore he was able to quit the job of a conservatory professor to dedicate himself exclusively to composing (as of the autumn of 1878).

In the spring of 1877 he married Antonina Milukova, whom he met a mere few weeks before $^{10}$. The marriage was doomed from the start manly because P. Tchaikovsky wished to dispel the mounting allegations (appearing even in the press) of his unnatural sexual inclination ${ }^{11}$. Two months after the wedding, when its consequences began to dawn on him, he suffered a strong nervous breakdown and made an exaggerated if laughable attempt on his life. Upon consulting a doctor he decided to separate from his wife. Paradoxically, that moment ushered in the most prolific period in P. Tchaikovsky's life. Living alternatively abroad and in Russia (mainly in Moscow and Petersburg), he composed his successive symphonies, ballets, operas, etc.

In 1890, Nadezhda von Meck unexpectedly notified the composer in a letter that she would no longer pay out the allowance due to her alleged poor finances and that she would no longer correspond with him; the composer's repeated attempts to come to some understanding were to no avail.

In 1893, the composer received an honorary doctorate at Cambridge University for his oeuvre and its European character. The artist died that very year (October 25/November 6) in Petersburg at the age of 53. Nadezhda von Meck outlived Pyotr by only months.

For a long time, the artist's death was shrouded in mystery and was most often explained by the cholera epidemic. This explanation was offered in Tchaikovsky's biography written by the composer's brother Modest Tchaikovsky, who wanted to hide the uncomfortable past in the composer's biography. Today, some researchers openly say that the reason for the artist's death could have been a forced suicide resulting from the fear of exposing a moral

\footnotetext{
8 E. Dziębowska, op. cit., p. 281.
}

9 S. Mundy writes about an accidental meeting during a stroll in the forest in 1879 . However, they passed each other without saying a single word, which they both considered almost a misfortune in their correspondence. This "misfortune" occurred in Brailovo, Nadezhda's estate, despite the fact that Tchaikovsky had been sent a schedule of von Meck's activities to plan his stay to avoid such an incident. A year earlier the composer also stayed there, agreeing with his protector that he would go to Brailovo at such a time as not to find her there. Nevertheless, the servants were to fulfil all the guest's wishes, unaware of his relationship with the lady of the house. In the same year, Mrs. von Meck rented an apartment for Pyotr, who was in Florence at the time, and she was nearly his next-door neighbour. It seems that the desire for absolute isolation was more characteristic of Pyotr; after all, Nadezhda confessed her love for him in a letter. However, no rash conclusions should be drawn from this unusual interpersonal relationship. Pyotr knew perfectly well that in case of a direct meeting he would be able to find an excuse for the impossibility of their physical intimacy. In such a case, the cordiality that Nadezhda lavished on him in her letters would cool down with generosity, which she herself expressed in one of her last letters. See S. Mundy, op. cit., pp. 120, 138, 145, 150-151, 218.

10 The composer met Antonina Milukova when she was still a teenager in 1865 . When she was a student in the Moscow Conservatory a few years later, Tchaikovsky was unaware of her infatuation with him and maintained a typical teacher-student relation. See S. Mundy, op. cit., p. $121 \mathrm{ff}$.

11 See ibidem, pp. 122, 143. 
scandal $^{12}$. Modest, a homosexual himself ${ }^{13}$, implied that Romeo and Juliet was inspired by Pyotr Tchaikovsky's unfulfilled love for an old schoolmate.

$* * *$

The idea to render through music the history of Romeo and Juliet was suggested to Tchaikovsky in the summer of 1869 by a recently met, older and more experienced if lesser known composer Mily Balakirev, the chief ideologist of a group of composers known as The Mighty Handful (Могучая Кучка) ${ }^{14}$. He as much as dictated to Tchaikovsky how the work should be composed, mapped out the principal line and the entire work, including the modulation and other technical details. Proposing the Romeo and Juliet theme, Balakirev was probably aware that at that time Tchaikovsky was still infatuated by the Belgian soprano Désirée Artôt, whom he had met a few months before.

Initially the composer gave in to his colleague and within a dozen weeks or so the work was completed $^{15}$. When the score was read by the composers of The Mighty Handful, despite some critical comments they admired it to such an extent that Vladimir Stasov, a music critic and author who had a marked impact on the music development in Russia, on the spur of the moment included P. Tchaikovsky into the above group and observed: Now there are six of $y o u^{16}$, which naturally was not true. The overture premiered in Moscow in March 1870 and was directed by his former teacher Anton Rubinstein. Interestingly, the reaction of the audience was moderately enthusiastic, to put it mildly, and we know that the Russians are a nation with great musical talents. The author of this article may back up the opinion of Alfred Einstein ${ }^{17}$, a German musicologist, with his own observations ${ }^{18}$.

Oversensitive to the treatment of himself and his art, in the summer of that year the composer left first for Petersburg and then for Paris, where he always felt at home. There he began to introduce corrections to the Romeo and Juliet overture, rightly believing that the overture itself is partly to blame for the far from enthusiastic reception of the work. When returning home, he had already completed a new version of the work and had rejected M. Balakirev's suggestion. While the composition was not written down, its details were already adopted by the composer ${ }^{19}$.

However, two other years elapsed before the work (ultimately defined by the composer as a fantasy-overture ${ }^{20}$ ) was performed. Mily Balakirev observed that this was by far Tchaikovsky's best composition to date. In fact, it fully demonstrates the composer's extraordinary talent for creating lyrical melodies (cf. the middle part of the violin concerto D), which on the

\footnotetext{
12 A. Holden, Tchaikovsky. A Biography, New York 1998.

13 S. Mundy, op. cit., p. 113.

14 The Mighty Handful were a group of composers promoting Russian national dance music. While Pyotr Tchaikovsky was not a member, he yet held social relations with the Five. See A. Einstein, Muzyka w epoce romantyzmu, transl. M. and S. Jarocińscy, Kraków 1983, p. 335.

15 See S. Mundy, op. cit., p. 87.

16 Ibidem.

17 A. Einstein, op. cit., p. 322.

18 The author of the article has for several years held regular classes for students of the School of Church Music in Moscow.

19 S. Mundy, op. cit., pp. 87-88.

20 Tchaikovsky really had problems maintaining the clarity of form. A. Einstein, Muzyka w epoce romantyzmu, p. 336.
} 
one hand made him famous and on the other exposed him to the derision of musical snobs. A revised version of Romeo and Juliet immediately brought P. Tchaikovsky recognition in the West, when in 1871 it came out in print in the Berlin-based Bote und Bock Press ${ }^{21}$. That the new version of the overture was favourably accepted, interestingly first in Germany, ${ }^{22}$ moreover proves a difference of class between M. Balakirev and P. Tchaikovsky. We may wonder today if the Romeo and Juliet overture would have made a success had Tchaikovsky not followed M. Balakirev's advice and persisted in his vision of the work, as he did with respect to Anton Rubinstein in the case of the Piano Concerto in B flat minor.

There are three versions of the work ${ }^{23}$. The final, third version of Romeo and Juliet, which became the performed standard, was completed in 1880 in Brailovo. It premiered in Tbilisi only in 1886. Finally, rather than depict the events in the order they appear in the tragedy, Tchaikovsky actually creates changing moods via the use of contrast.

The idea of thematic contrast is the chief principle of construction of the classical sonata, the basis for instrumental sonatas, symphonies and concertos. This is also the form of Romeo and Juliet, later dubbed by the composer the fantasy-overture, although in general terms this is a symphony poem with an introduction and epilogue. The first theme, in the principal key, usually played at the beginning, is effervescent and "masculine". It is followed by the second theme, more lyrical and pliable for the sake of contrast. This theme, which can be called "feminine", is in the dominant key. Rarely does a composer decide to reverse the order of the themes ${ }^{24}$. Once the two themes are presented, they are merged in a free arrangement, followed by a reprise, or a reiteration of both themes in the "concordant" and unified main key. This very general patterns of the sonata has its variations, which however will not be discussed here.

Leaving aside the question of exact inspiration, let us closely regard the work itself. Pyotr Tchaikovsky applied here the form of the sonata parallel to two literary motifs of Shakespeare's tragedy: hate and love (in this order), rendering the duality of both affections via divergent music means.

Romeo and Juliet opens up with a cheerful F sharp minor tune led by clarinets and bassoons, an introduction to the short composition of ca. twenty minutes. The tune seems to represent Friar Lawrence, the lovers' ally.

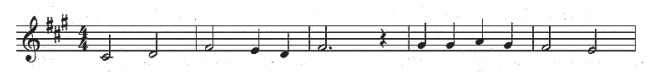

Fig. 1 - Friar Lawrence's theme

The purposely antiquated, pseudo-liturgical character of the melody justifies its linkage to the figure of a priest. Before long, the melody is taken over by the orchestra, which performs

\footnotetext{
21 The composer would mainly publish his work in Bessel's and Jurgenson's publishing houses. See S. Mundy, op. cit., pp. 90, 105.

22 In 1876, especially in Vienna, but also in Paris, the overture did not have favourable reviews. Apparently, P. Tchaikovsky's cosmopolitan music was liked more in Germany, England and the United States.

23 See T. Chylińska, S. Haraschin, M. Jabłoński, Przewodnik po muzyce koncertowej, Part I, Kraków 2003, pp. 268-269.

24 The best-known examples of a reversed order of themes are L. van Beethoven, "Moonlight" piano sonata No. 14 in C sharp minor, Op. 27, No. 2. There is even a case of an absence of the second theme: W.A. Mozart, "Haffner" Symphony no. 35 in D major, KV 385.
} 
it in a lofty mood ${ }^{25}$. Despite the bombastic nature of the moment, the inevitable drama is foreshadowed by the ominous-sounding double basses and broad intervals in the violin part.

The turbulent first theme, the theme of hatred, reflecting via the instrumental clatter the hate of the feuding of Montecchi and Capuletti families, is increasingly becoming more and more tense, occasionally only fading away.

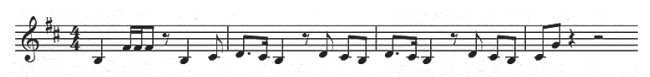

Fig. 2 - the hate theme

A moment later, after the first theme has been heard, at the climax of this dramatic episode, the composer introduces an extremely artistic, lyrical second theme, the theme of love. It is led by the English horn and flutes against a background of delicate orchestra accompaniment in the fluctuating dynamics and fluent variability of rising, consonant chords. Despite its delicate nature, the harmony is quite clearly saturated with dissonant chords.

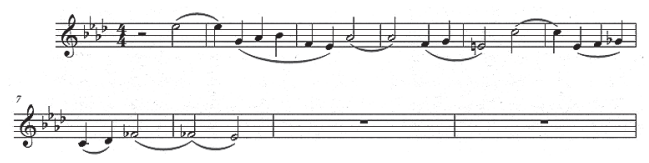

Fig. 3 - the love theme

This particular fragment brings to mind a romantic love scene between Juliet and Romeo. M. Balakirev must have paid special attention to this theme, praising Tchaikovsky's inventive melody; indeed, it has a masterful cantilena and intriguing supplementary harmony.

Both the themes will recur in the reprise, yet in an altered form: the theme of love was truncated and dominated by or subjugated to that of hate in its culmination interrupted by the timpani. P. Tchaikovsky's characteristic use of the violins in the high register and their execution of a flexible melody ${ }^{26}$ can be also found in the reprise of Romeo and Juliet.

This new form of the themes finally disappears in a serious mood of the minor key, symbolising the approaching tragic finale of the lovers' history. For the last time, the theme of love will resound and terminate in four bars of violent chords and two beats of cymbals, announcing the deaths of the two lovers. Once again, a note of melancholy is heard, the same one that resounded at the beginning of the work; now it depicts the scene of the belated arrival of Friar Lawrence, who could no longer prevent the suicides. This melancholy ending can also be read as the union of the two protagonists in the afterlife ${ }^{27}$.

As we know, the feuding families were reconciled only at their children's graves. Pyotr Tchaikovsky rendered this forced reconciliation literally with the final sounds: first we hear one last time the gingerly marked theme of love, followed by a consonant orchestra chord

25 T. Chylińska, S. Haraschin, M. Jabłoński, op. cit., p. 269.

26 E. Dziębowska, op. cit., p. 304.

27 T. Chylińska, S. Haraschin, M. Jabłoński, op. cit., pp. 269-270. 
that will become a single, shared sound. It would be hard to find a more musically distinct symbol of harmony and accord.

$$
* * *
$$

The 23 April 1616 was the day of death of two giants of European literature: William Shakespeare and Miguel de Cervantes ${ }^{28}$. Their significance and contribution to culture proves that language may transcend reality and create rather than merely describe it. Martin Lings, a British converted Muslin, one of the greatest commentators of Islam, in the excellent book The Secret of Shakespeare implied that his tragedies, when properly read and understood, are in fact works about God. According to Lings, for 400 years we have wrongly interpreted Shakespeare's oeuvre believing that it strongly and solely focuses on the human being. This is a "humanistic" interpretation. M. Lings makes an intellectual breakthrough, placing Shakespeare within sacred art: "In the theocratic civilizations, if an artist himself was not an intellectual, he none the less obeyed the canons of art which had been established on an intellectual basis. A mediaeval portrait is above all a portrait of the Spirit shining from behind a human veil"'29.

Shakespeare's tragedy and Pyotr Tchaikovsky's complicated personal life merged to bear a magnificent fruit of the composer's mastery, which helped him contain the Shakespearean drama within a mere 20 minutes of music, alternatively very dramatic and evocatively lyrical. The composition continues to dazzle until today and the subject of love has been used in TV series and films, e.g. The Jazz Singer (1927, the first sound movie!), South Park, A Christmas Carol, and The Three Musketeers.

It is no doubt worthwhile to listen to the entire enthralling composition. While the term "enthralling" is not exactly a scholarly one, it is particular to the language of aesthetics. However, when addressing in scholarly terms a musical work, one cannot entirely abstain from aesthetics.

\section{Romeo and Juliet by Pyotr Tchaikovsky. The 400th Anniversary of William Shakespeare's Death Summary}

With the biography of P. Tchaikovsky in the background, the author describes the circumstances of the creation of the overture Romeo and Juliet. Then he briefly analyses the composition itself and describes its character.

Keywords: P. Tchaikovsky, music, Romeo and Juliet, W. Shakespeare

About the Author: Prof. Dr Hab. Czesław Grajewski, (b. 1960), in 1986 graduated cum laude in Musicology from the Warsaw Theological Academy (now Cardinal Stefan Wyszyński University). The supervisor of his MA was Fr. Prof. Dr. Hab. Jerzy Pikulik. In 1995 he earned his doctorate upon completing the dissertation Antyfonarz gnieźnieński ms. 94-97

\footnotetext{
28 Actually, different calendars were used in Spain and England, hence both literary celebrities officially died on two consecutive days, but the dates of their deaths were aligned after the calendars were unified.

29 M. Lings, The Secret of Shakespeare, London 1984, p. 12.
} 
w świetle tradycji polskiej i ogólnoeuropejskiej (Gniezno Antiphonary ms. 94-97 in light of Polish and pan-European tradition; supervisor: Fr. Prof. Dr. Hab. Jerzy Pikulik). In 2001 he was employed by his Alma Mater, until 2004 being a lecturer of practical subjects at the Faculty of Historical and Social Sciences. In 2005 he earned his post-doctoral degree on the basis of the dissertation Formuly dyferencyjne psalmodii brewiarzowej w źródtach polskich (Differential formulae of breviary psalms in Polish written records) and got successively promoted: 2006-2007 he was assistant professor in the Department of Old Music Sources and Analyses, in 2006-2014 headed the Department. Between 2007 and 2015 he led the Specialty of Theoretical and Applied Musicology at Cardinal Stefan Wyszyński University. In 2015 he earned the professorial title in the humanities and now is a faculty member of the Department of Old Art in the Cardinal Stefan Wyszyński University Institute of Art History.

His research focuses on the sources of Polish medieval antiphonaries, European tonary missals and selected issues of contemporary Polish sacred music. He is also an active church musician. 